\title{
Study on Collaborative Innovation of Ideological and Political Education for College Students in the "Internet +" Age
}

\author{
Wenjuan Liu \\ Shandong Xiehe University, No. 6277 Jiqing Road, Licheng District, Jinan City, Shandong Province, China; \\ 250109
}

Keywords: collaborative innovation; Ideological and Political Education; college students; "Internet +" Age

\begin{abstract}
With the globalization of economy, informatization of science and technology, and diversified flows of ideology and culture, China's higher education and ideological and political education for college students are facing severe challenges. Faced with the new situation and new requirements, ideological and political education needs all-round, full-fledged elements, and collaborative innovation throughout the entire process. It is essential to take the concept of innovation as the guidance, and strive to build an education framework in an all-round, synergistic way to educate people; Efforts should be made to ensure the effectiveness of education for all elements, and to ensure management innovation, strive to improve and perfect the long-term mechanism for all employees to cooperate and educate people. Carrier innovation is taken as the starting point, to strive to create an education environment for collaborative education in the whole process and make great efforts to create a new situation of ideological and political education for college students.
\end{abstract}

\section{Introduction}

"Internet +" is the "Internet + traditional industry". The real economy of the traditional industry realizes cross-border integration and collaboration through the Internet platform, breaking the traditional social structural order, and achieving cross-industry, cross-domain, and cross-indication on invisible Internet platforms. This innovative development of production methods and lifestyles will trigger a series of reforms and developments at the social level. Postgraduate ideological and political education has always been a relatively weak link in university ideological and political education. In recent years, under the influence of "Internet+", China's postgraduate higher education has been constructed through networks from the media in addition to education methods, education methods, and educational content. The wider public sphere; the opening of the "Internet Plus" has also brought new problems and new challenges to postgraduate ideological and political education. This has brought graduate students' ideological and political education into the new normal with the reform and development of graduate education.

\section{Ideological and Political Education of College Students in the Age of "Internet+"}

Under the premise that the predominant position of the dominant ideology does not change, the struggle between mainstream and non-mainstream ideas for the continuous discourse right will become the new normal. According to the newly released 2015 China New Media Development Report, China has become the world's largest new media market. Various types of self-media have developed rapidly, and the convergence of media has accelerated. From the Internet of Things, cloud computing, and big data to now the most popular mobile phone We-Chat in the media, the Internet public opinion has begun to play a special role, and its influence has continued to increase. According to a sample survey conducted by a college of East China University of Science and Technology in April 2014, 100\% of postgraduates have opened and widely used We-Chat... The graduates of the college have used We-Chat for more than 2 hours a day, in addition to experimenting, writing papers, and eating. Sleep and physical exercise, most of the rest of the time 
is on the mobile We-Chat." Micro-transmission as a mainstream transmission mode, through the extensive use of mobile We-Chat and graduate recruiting for successive years of enrollment, has become very popular in the growing number of graduate students Coverage and influence. The media occupation of the Internet and online media is an important position that no social trend will ever give up. China's socialist core value system with Marxism as its guiding ideology has always led the social ideological trend and consolidated social consensus. However, with the globalization of the economy and the rapid development of the Internet from the media and high-tech information technology, many Western social trends continue to flood universities. Social ideology, as a comprehensive manifestation of ideology that is systematic, influential, and represents a certain social class interest or concept, will often have a certain impact or even impact on people's ideological, political, and cultural fields. The influx of western social thoughts is not because of the indifference to cyber politics. On the contrary, these social thoughts have very strong ideological attributions. "A variety of social trends of thought, although they have a wide range of influence on people's ideas, will eventually have more or less connections with the social ideological and political concepts or ideologies of our country, and will eventually affect or interfere with our social ideology.” Some Western non-mainstream social thoughts contend for discourse power in the public sphere of the Internet. Their essence is to provoke the leadership of the Communist Party of China, to promote and intentionally sell non-Marxist ideas or even anti-Marxist ideas and to "Westernize" China." Divide the "peaceful evolution" plot. For a long time to come, the struggle between the mainstream and non-mainstream ideas in the Internet and online media will become the new normal.

Actively reforming the traditional postgraduate ideological and political work system, making full use of new media tools to open the quality of graduate education to the public and accepting public supervision will become the new normal. In recent years, with the expansion of postgraduates for professional degrees, the number of postgraduate students has increased and the types of school systems have become increasingly miscellaneous. New problems have arisen in the enrollment, employment, and training of graduate students, and in the life, study, and management of graduate students. In 1978, China resumed the enrollment of graduate students, and in 1987 it promulgated the "Decision on Improving and Strengthening the Ideological and Political Work in Colleges and Universities". In the same year, the National Education Committee Party Committee and the Central Propaganda Department issued "Opinions on Strengthening Postgraduate Ideological and Political Work," 2000 Education. The Ministry promulgated "Several Opinions on Strengthening and Improving the Moral Education of Postgraduate Students." The ideological and political education work for graduate students in our country has gradually received attention and is actively conducting relevant practical explorations. However, at present, the postgraduate ideological and political work system in China is still in a certain period of bottleneck development. The main manifestations are: There is no system for ideological and political education for graduate students. Most of them follow the methods of ideological and political education for undergraduates, under the leadership of the college clerk. The ideological and political education of postgraduates is part-time by full-time instructors or subject secretaries. In the traditional management model, strong management awareness, a single management model, lack of communication with mentors and graduate students, and the demand for postgraduate ideological and political education and the law of graduate ideological and political education cannot be truly understood. With the rapid development of the Internet from the media, the management of graduate students has become more open and transparent. Graduate students, tutors, social organizations, and the media are increasingly concerned with the quality evaluation mechanism of post-graduate higher education. In the past, the status of closed cultivation and self-cultivation of graduate students has undergone tremendous changes. The ideological and political education mode and training mode suitable for graduate students have been actively explored, and the quality of postgraduate education has been fully utilized by new media tools. Accepting public supervision will become a graduate education.

Pay attention to the construction of postgraduate moral education. While developing postgraduate academic quality and carrying out academic exercises, actively cultivate 
postgraduates' sound personality and outstanding personality have become the new normal for postgraduate training. In the cultivation and education of postgraduate students in our country, it has been found that graduate students are less focused on academic research, and that the impetuous psychology of pursuing higher education and satisfying job demands is getting heavier. The academic ethics and academic atmosphere of postgraduate students are increasingly worrying. Academic corruption, plagiarism and other academic disorders are serious. "The essence of postgraduate ideological and political education is to promote the overall development and healthy growth of postgraduates. The new situations, new problems and new features that have emerged among postgraduate students have directly affected the growth and development of graduate students." There is one academic education for graduate students. In the process of academic research and creation, many graduate students are often obsessed with worshipping and imitating academic authority because they don't have enough solid basic knowledge or lack the pursuit of cutting-edge issues in the field, and they stay in this initial stage of learning, neglecting or Not dare to challenge academic authority, resulting in a grim situation in postgraduate moral education. In the age of network information, higher requirements are placed on the moral quality and moral standards of postgraduate and graduate student advisors. Although affected by various non-mainstream ideas, the value standards tend to be utilitarian, and the differences among groups of thoughts are relatively large. However, the mainstream thinking of graduate students is positive and the Internet age has also spawned the pursuit of graduate students. The characteristics of graduate education in China are insufficient, and many aspects are still in the exploratory period. The education, training, management, and service of graduate students are still not perfect in many aspects. In particular, there is disconnect between the demand and supply of postgraduate education resources. The training objectives and training process of postgraduate students are not clear. Many graduates of professional graduates cannot be clearly distinguished from the graduates of academic degrees. Postgraduate education is often tied to universal education. The development of post-graduate education calls for a sound personality and personal training will become the new normal.

\section{The Connotation of the Collaborative Innovation Mechanism for College Students' Ideological and Political Education}

The original meaning means that in certain structures, all elements are "ordered, self-organized collective behaviors governed by common laws". The ideological and political education of college students also consists of a certain number of factors. Taking the educated as the center, the ideological and political education can be divided into ideological and political education in professional disciplines, ideological and political education in management systems, and ideological and political education in campus culture. The three structural elements become the three fulcrums for educators to receive ideological and political education. With this as a starting point, through the study of the value of professional disciplines, management systems, and campus culture in the function of ideological and political education, the basic tactics for ideological and political education are proposed so that the process of ideological and political education runs through the entire university life of educated people. Further, the orderly distribution of fragmented ideological and political education resources, and the realization of a new operating mechanism for ideological and political education that can be taught anywhere and everywhere, is the basic connotation of the collaborative innovation mechanism for the ideological and political education of college students.

\section{The Strategies to Build a Collaborative Innovation Mechanism of the Ideological and Political Education for College Students}

The construction of the collaborative innovation mechanism for college students' ideological and political education is centered on professional disciplines, management systems and campus culture. It focuses on the value of the three elements in ideological and political education, and then realizes the mechanism for the coordinated operation of ideological and political education resources. 
The various forms of knowledge are interlinked, and "fitness is the ultimate goal of knowledge". Ideological and political education can be fully integrated into all aspects of professional learning of college students. Taking the discipline of natural science as an example, natural science knowledge has rich moral implications. For example, ideals, patience, perseverance, carefulness, opportunities, and other non-intelligence factors that affect the discovery of scientific knowledge have played an important and even important role in the process of scientific knowledge discovery. Non-intelligence factors as the basic content of ideological and political education are taught in natural science majors. Students accept it more positively than in ideological and political lessons and have a strong sense of identity. Scientific workers also need to observe Ethical norms such as honesty and truthfulness, and ecological ethics generated during the application of science and technology. If teachers conduct guidance at the right time in class, explain the interests of them, and students observe through practice, they will pay more attention to the importance of being honest, pursuing the truth, understanding the environment, and building a socialist civilization.

Ideological and political education literacy refers to the consciousness of ideological and political education in the minds of professional teachers and the ideological and political education ability demonstrated in the teaching process. The ideological and political education literacy is measured in two aspects: First, how much is grasped in the ideological and political education theory contained in this professional knowledge, and second is the ability to perform relevant ideological and political education in the process of deconstructing professional knowledge. Most professional teachers do not pay much attention to ideological and political theory courses, but they do not reject ideological and political education. This shows that professional teachers hope to improve their ideological and moral conditions through their own courses. In the past teaching, many professional teachers did not specifically explore the implicit educational resources in the curriculum, and lacked the enthusiasm to integrate professional knowledge learning with ideological and political education, which led to the long-term disconnect between students' professional learning and ideological and political education. This requires that professional teachers carefully find out in the process of knowledge preparation that they can serve as a point of ideological and political education, and adopt appropriate teaching methods to deconstruct these ideological and political education points in an appropriate manner, and integrate ideological and political education in the process of teaching professional knowledge.

How to carry out hidden curriculum development in ideological and political education, and where schools can arrange hidden course is problem that educators need to define clearly. Some researchers propose that the following places and environments can constitute the school's recessive curriculum: "The school library is full of cultural atmosphere, strong academic atmosphere, inspiring spirit, advocating and pursuing truth, and safeguarding ethics. Traditional cultures, elegant campus landscapes and other organic cultural environments all constitute the school's recessive curriculum.” Therefore, a college's university spirit, management system, and campus history can all become ideological and political education. To be specific, a university must have a very clear university spirit so that freshmen can be exposed to the recessive education environment at the beginning of the school year, and thus have the effect of the "stability or durability" of education. Once this implicit education is recognized by students, the impact it will have will be lifelong.

\section{Conclusion}

In the "Internet Plus" era, the links in the ecological and ecological environment of college students' ideological and political education have undergone tremendous changes. In the new era, undergraduates' ideological and political education can no longer be dissociated from the "Internet+" paradigm. Instead, they must actively integrate into the network and integrate traditional ideological and political education into a new network of ecological chains. The traditional methods and methods have been transformed and transformed into new brilliance. In the era of "Internet+", the ideological and political education of college students must always adhere to the student-centered education philosophy, adhere to the correct guidance of the ideological public opinion, and persist in guiding the ideology of college students. This is the essence of ideological 
and political education.

\section{Acknowledgements}

Fund Project: 2016 Social Sciences Planning Research Project of Shandong Province (Specialization of Ideological and Political Education in Colleges and Universities) "Study on Collaborative Innovation of Ideological and Political Education for College Students in the "Internet Plus" Age"(Project Number:16CKSJ16)

\section{References}

[1] You Nina, Huang Riqian. New media and college students' ideological and political education [M]. Beijing: Guangming Daily Press, 2016

[2] Sun Guangyao. Research on college students' ideological and political education in the era of new media[M]. Xi'an: Northwestern Polytechnical University Press, 2017.12

[3] Yang Kun. Cultivation and research of college students' innovative ability [M]. Beijing: Jiuzhou Publishing House, 2017

[4] Ji Qianyu. Research on Ideological and Political Education Innovation from the Perspective of New Media[J]. Educational Theory and Practice, 2016(3)

[5] Ji Haiju. Research on ideological and political education in universities in the era of new media [D]. Dissertation of Nanjing Normal University, 2013 